\title{
Caloric Content of Rocky Mountain Subalpine and Alpine Plants
}

\section{DOUGLAS C. ANDERSEN AND KENNETH B. ARMITAGE}

Highlight: Caloric equivalents for aboveground parts of Rocky Mountain subalpine and alpine herbaceous plants averaged $4,859 \mathrm{cal} / \mathrm{g}$ ash-free oven-dry weight. A sh content averaged $9.8 \%$ for 17 forbs. Both caloric content and ash content ranged higher than values for alpine species from New Hampshire.

Knowledge of the caloric equivalents of primary producers is required in studies examining herbivore bioenergetics, including analyses of energy flow through ecosystems. Few values of caloric content are available for the subalpine and alpine flora of the Rocky Mountains. Further, reports in the literature may not be comparable or complementary, due to differences in measurement techniques. For example, Smith (1967) presented values from air-dried material while Bliss (1962) gave values based on ash-free oven-dry weights.

Authors were graduate student, Museum of Natural History and Department of Systematics and Ecology, University of Kansas, Lawrence 66045; and professor, Division of Biological Sciences, University of Kansas, Lawrence. Andersen is currently with the Department of Biology, Utah State University, Logan 84322.

This work was supported by N.S.F. Grant GB32494 to K. B. Armitage.

Manuscript received October 17, 1975.
Without knowledge of the ash content of the plant species (or even families) involved, comparison of these values is meaningless. Differences in the parts of plants included in analyses compound difficulties in direct comparison of caloric equivalents, since above- and below-ground portions of plants may differ significantly (Rochow, 1969).

Bliss (1962) and others have suggested that the energy content of ecological materials should be determined for specific environmental situations, since individual species may show both seasonal and spatial variation in caloric content (Golley, 1961; Bliss, 1962; Hadley and Bliss, 1964; Rochow, 1969). However, in studies where broadly based temporal or spatial averages are most appropriate, complementary estimates remain desirable. We determined the caloric content for various aboveground parts of subalpine and alpine plants in conjunction with a bioenergetic study of yellow-bellied marmots. Our values are presented here to aid and stimulate further studies of energy dynamics in high montane environments.

\section{Methods}

Samples of various species of grasses, sedges, and forbs (Table 1) were collected from a series of quadrats randomly located within a 7-ha portion of North Pole Basin, Gunnison 
Table 1. Caloric contents of aboveground portions of alpine and subalpine plants from North Pole Basin, Gunnison County, Colorado. Where ash content could not be determined due to insufficient material, estimates were assigned, based on either closely related species or the category "herbs." S.D. = standard deviation of sample population of size $n$.

\begin{tabular}{|c|c|c|c|c|c|c|c|}
\hline \multirow[b]{2}{*}{ Species } & \multirow[b]{2}{*}{ Plant parts ${ }^{1}$} & \multicolumn{3}{|c|}{$\begin{array}{l}\text { Caloric content } \\
\text { (ash-free weight) }\end{array}$} & \multicolumn{3}{|c|}{$\begin{array}{c}\text { Ash content } \\
\text { (\% of dry weight) }\end{array}$} \\
\hline & & $\mathrm{cal} / \mathrm{g}$ & S.D. & $\bar{n}$ & $\%$ ash & S.D. & $\mathrm{n}$ \\
\hline Mountain bluebell (Mertensia ciliata) & $\mathbf{L}$ & 5022 & 65.4 & 4 & 14.82 & 1.16 & 2 \\
\hline Thistle (Cirsium Hookerianum) & $\bar{L}$ & 5069 & 126. & 6 & 13.63 & 2.86 & 2 \\
\hline Rockcress (Arabis drummondii) & $\mathrm{S}, \mathrm{L}, \mathrm{F} 1$ & 4930 & 150. & 2 & 10.57 & & 1 \\
\hline Draba (Draba aurea) & $\mathrm{S}, \mathrm{L}, \mathrm{Fl}, \mathrm{Fr}$ & 4908 & & 1 & 10.17 & & 1 \\
\hline Wallflower (Erysimum asperum) & $\mathrm{S}, \mathrm{L}, \mathrm{Fl}, \mathrm{Fr}$ & 4901 & & 1 & 11.70 & & 1 \\
\hline Candytuft (Thlaspi alpestre) & $\mathrm{S}, \mathrm{L}, \mathrm{Fl}, \mathrm{Fr}$ & 4804 & 190. & 8 & 8.72 & 0.63 & 4 \\
\hline Sedges (Cyperaceae) $)^{2}$ & & 4696 & 100. & 9 & 6.55 & 0.84 & 6 \\
\hline Grasses (Gramineae) $)^{3}$ & & 4794 & 123. & 18 & 7.33 & 1.85 & 8 \\
\hline Parry clover (Trifolium parryi) & $\mathrm{S}, \mathrm{L}$ & 4842 & 100 & 2 & 10.0 & assigned & \\
\hline Dog tooth violet (Erythronium grandiflorum) & $\mathrm{S}, \mathrm{L}, \mathrm{F} 1$ & 4803 & 70.0 & 4 & 5.47 & 0.56 & 2 \\
\hline Death camas (Zygadenus elegans) & $\mathrm{S}, \mathrm{L}, \mathrm{F} 1$ & 4816 & & 1 & 9.01 & 0.23 & 2 \\
\hline Pygmy bitterroot (Lewisia pygmeae) & $\mathrm{S}, \mathrm{L}, \mathrm{FI}$ & 4154 & 108 & 2 & 0.74 & & 1 \\
\hline Marshmerigold (Caltha leptosepala) & S, L, Fl & 4918 & 165. & 8 & 9.37 & 1.86 & 6 \\
\hline Buttercup (Ranunculus sp.) & $\mathrm{S}, \mathrm{L}, \mathrm{Fl}$ & 4774 & 125. & 3 & 8.63 & 2.96 & 2 \\
\hline Sibbald ia (Sibbaldia procumbens) & $\mathrm{S}, \mathrm{L}, \mathrm{Fl}, \mathrm{Fr}$ & 4915 & 27.6 & 2 & 9.60 & 0.21 & 2 \\
\hline Beardtongue (Penstemon whippleanus) & $\mathrm{L}, \mathrm{F} 1$ & 4821 & 177. & 3 & 7.08 & 0.26 & 2 \\
\hline Speedwell (Veronica wormskjoldii) & $\mathrm{S}, \mathrm{L}, \mathrm{Fl}, \mathrm{Fr}$ & 5064 & 103. & 2 & 10.21 & 1.66 & 3 \\
\hline Lovage (Ligusticum porteri) & $\mathrm{L}$ & 5128 & 23.3 & 2 & 15.80 & 0.40 & 3 \\
\hline Wild parsley (Pseudocymopterus montanus) & $\mathrm{S}, \mathrm{L}, \mathrm{Fl}, \mathrm{Fr}$ & 4956 & 146. & 5 & 11.76 & & 1 \\
\hline Herbs $^{4}$ & $\mathrm{~S}, \mathrm{~L}$ & 4971 & 150. & 13 & 11.32 & 1.02 & 7 \\
\hline
\end{tabular}

${ }^{1} \mathrm{~S}=$ stems, $\mathrm{L}=$ leaves, $\mathrm{F} 1=$ flowers, $\mathrm{Fr}=$ fruits.

${ }^{2}$ Includes Carex ebenea.

${ }^{3}$ Includes Agropyron sp., Bromus marginatus, Deschampsia caespitosa, Phleum alpinum, Poa alpina, Poa sp., Trisetum spicatum.

${ }^{4}$ All unidentified herbaceous plants in vegetative phenophase.

County, Colo., between June 18 and July 12, 1974. The study area, a series of meadows bordered by krummholz, stands of tall willow, and bedrock outcroppings, occupied a portion of the floor $(3,380 \mathrm{~m})$ and lower sides of the narrow, northfacing basin. The vegetation generally characterized a weakly developed "upland herb" community (Langenheim, 1962) with typically alpine species in drier sites, and local concentrations of snowflush and streamside species. Snowpack regularly remains within portions of the study area through late July.

Aboveground portions of plants were collected, air-dried and stored 3-4 months until caloric determinations were made. Prior to bombing, samples were oven-dried at $60^{\circ} \mathrm{C}$ for at least 7 days, and subsamples pelletized after hand grinding with mortar and pestle. A Parr 1411 semimicrocalorimeter was utilized to determine caloric content. Ash content was determined by baking samples at $500^{\circ} \mathrm{C}$ for 4 hours. Subdivision by plant parts was made in a few cases where stems were excluded from the analyses. Plant parts listed in Table 1 generally reflect phenological stages present during the collecting period.

\section{Results and Discussion}

The caloric values for the entire aboveground portion of the plants examined ranged from an average of $4,154 \mathrm{cal} / \mathrm{g}$ ash-free oven-dry weight (cal/gad) to $5,064 \mathrm{cal} / \mathrm{gad}$, while ash content varied from less than 1 to more than $11 \%$ (Table 1 ). The species-specific variation we encountered between duplicate caloric determinations (average $1.4 \%$; range $0.0-3.7 \%$ of the mean) was larger than that experienced by other workers (Bliss, 1962; Malone, 1968; Rochow, 1969). This could be a result of relatively incomplete mixing of plant tissues in our hand-ground samples, compared to the mechanically ground samples of other workers.

For the 17 forbs examined, ash content averaged $9.8 \%$ of the oven-dry weight, higher than most values reported by Bliss (1962) for alpine plants in New Hampshire (generally under $1.5 \%$ ). The average caloric value for all identified herbaceous plants was $4,859 \mathrm{cal} / \mathrm{gad}$. This value is higher than the average of 4,601 cal/gad for New Hampshire plants (Bliss, 1962); however, direct comparison is dangerous since no common species are included. The caloric content of marshmerigold (Caltha leptosepala) shoots collected during early phenological stages at 3,231 $\mathrm{m}$ in Wyoming (Rochow, 1969) were not significantly different ( $5 \%$ level of confidence) from our mean value of $4,918 \mathrm{cal} / \mathrm{gad}$.

The caloric value we determined for grasses represents an average weighted by the abundance of each species within the sample plots. Our value of $4,794 \mathrm{cal} / \mathrm{gad}$ is significantly higher than the average value for grasses collected in New Hampshire alpine, either at a comparable time, or later in the growing season, when fruiting was more prominent (Bliss, 1962). If the Rocky Mountain alpine grasses examined by Smith (1967) are assigned a $10 \%$ ash content, and caloric content recalculated, the earliest collection (July 12 ) retains an average value significantly below ours. However, it is higher than the average for the New Hampshire alpine grasses, and further increases in the caloric content of each species would result if corrections could be made to allow for the higher moisture content in the air-dried samples utilized.

\section{Literature Cited}

Bliss, L. C. 1962. Caloric and lipid content in alpine tundra plants. Ecology 43:753-757.

Golley, F. B. 1961. Energy values of ecological materials. Ecology 42:581-584.

Hadley, E. B., and L. C. Bliss. 1964. Energy relationships of alpine plants on Mt. Washington, New Hampshire. Ecol. Monogr. 34:331-357.

Langenheim, J. H. 1962. Vegetation and environmental patterns in the Crested Butte area, Gunnison County, Colorado. Ecol. Monogr. 32:249-285

Malone, C. R. 1968. Variation in caloric equivalents for herbs as a possible response to environment. Bull. Torrey Bot. Club. $95: 87-91$.

Rochow, T. F. 1969. Growth, caloric content, and sugars in Caltha leptosepala in relation to alpine snowmelt. Bull. Torrey Bot. Club 96:689-698.

Smith, D. R. 1967. Gross energy value of aboveground parts of alpine plants. J. Range Manage. 20:179-180. 